\title{
Priorities of Agricultural Credit Cooperation Development
}

Klychova G.S*.

Kazan State Agrarian University, 420015, Russian Federation,

Republic of Tatarstan, Kazan, Karl Marks street, 65

\section{Nizamutdinov M.M.}

Kazan State Agrarian University, 420015, Russian Federation, Republic of Tatarstan, Kazan, Karl Marks street, 65

Safiullin L.N.

Kazan Federal University, Kazan, 420008, Russia

\section{Mavlieva L.M.}

Kazan State Agrarian University, 420015, Russian Federation, Republic of Tatarstan, Kazan, Karl Marks street, 65

\section{Doi:10.5901/mjss.2014.v5n18p215}

\section{Abstract}

Credit cooperation closely links the small forms of farming with financial market of the country and offers investors a new sphere of their capital application $f$. Shown importance high level of crediting limits new borrowings for updating funds and replenishment of circulating assets, especially during the period of preparation for spring field work and harvesting company. The mechanism of agricultural credit consumer cooperation functioning has been worked out as priority direction of agroindustrial complex development.

Keywords: Agriculture, agricultural credit consumer cooperation, state program, subsidies, loans, small forms of farming.

\section{Introduction}

By the results of 2013 the volume of gross agricultural production in the Republic of Tatarstan totaled to 160.6 billion rubles, with the index of production equal to $97.8 \%$. Of course, if weather conditions were kept as favorable as before 2009 , the Republic would have agricultural products 1.5 times more.

Table 1. Dynamics of the Republic of Tatarstan gross output in agriculture

\begin{tabular}{|l|c|c|c|c|c|c|}
\hline \multirow{2}{*}{ Indexes } & \multicolumn{7}{|c|}{ Years } \\
\cline { 2 - 7 } & 2008 & 2009 & 2010 & 2011 & 2012 & 2013 \\
\hline Gross agricultural production, billion Rub & 117,3 & 116,5 & 104,1 & 150,4 & 150,1 & 160,6 \\
\hline Production index, \% & 108,8 & 100,8 & 67,8 & 150,5 & 92,5 & 97,8 \\
\hline
\end{tabular}

Each percentage point of drop - it is approximately minus 2 billion rubles of products, the same is potentially lost revenue for farms. The table shows that the republic has serious physical indexes of production. 
Table 2. Dynamics of production and efficiency of the main agricultural products

\begin{tabular}{|l|c|c|c|c|}
\hline \multirow{2}{*}{ Types of products } & \multicolumn{4}{|c|}{ Years } \\
\cline { 2 - 5 } & 2008 & 2012 & \multicolumn{2}{|c|}{2013} \\
\cline { 2 - 5 } & Produced & Produced & Produced & Profitability, \% \\
\hline Grain weight after processing, m.t. & 5,7 & 2,9 & 2,6 & +15 \\
\hline Sugar beet, $\mathrm{m} . \mathrm{t}$ & 1,8 & 2,01 & 2,08 & +19 \\
\hline Potatoes, m.t & 1,6 & 1,37 & 1,32 & +12 \\
\hline Milk, thou., t & 1821 & 1883 & 1721 & +14 \\
\hline Livestock and Poultry, thou. tn. & 391 & 452 & 477 & -7 \\
\hline Eggs, billion pc. & 1,019 & 1,121 & 1,073 & +11 \\
\hline
\end{tabular}

Unfortunately, it is not accompanied by the required efficiency. Agricultural economy remains very problematic, because without state subsidies a few farms would have profit. Loss without subsidies in 2013 has amounted to 6.5 billion rubles and accounting subsidies - to 3.5 billion revenues. Even with the subsidies, every sixth venture is unprofitable.

Table 3. Financial performance of agricultural enterprises of Republic of Tatarstan

\begin{tabular}{|l|c|c|c|c|}
\hline \multirow{2}{*}{ Indexes } & \multirow{2}{*}{ Units } & \multicolumn{3}{|c|}{ Years } \\
\cline { 3 - 5 } & & 2011 & 2012 & 2013 \\
\hline Number of farms & number & 536 & 512 & 497 \\
\hline including profitable & $\%$ & 83 & 84 & 84 \\
\hline Losing & $\%$ & 17 & 16 & 16 \\
\hline Profit, total. & Bill rub & 5,2 & 5,8 & 3,5 \\
\hline Profitability, total & $\%$ & 10,6 & 10,4 & 6,3 \\
\hline Profitability (loss) minus subsidy & $\%$ & $-28,4$ & $-21,2$ & $-11,3$ \\
\hline
\end{tabular}

Maintaining efficiency of the industry management, the share of unprofitable enterprises is kept at $16 \%$, at the same time the share of ineffective agricultural units has been reduced by half without accounting of subsidies. While as of the end of 2011 this figure was - $28 \%$, then in 2013 - it was $11 \%$ [3, 5, 6, 11].

Russia for more than a year works as a member of the World Trade Organization (WTO), and often this poses a problem of competitiveness before agricultural producers. Of course, it is difficult to compete with European countries, as they have energy supply 3 times higher and incomparable budgetary support. To date, energy supply per 100 hectares of crops in RT is $160 \mathrm{hp}$, which is 3-4 times less than the supplying of the farmers in Europe (304 hp) and in the USA (603 hp) [4].

Weak energy supply of farms does not allow performing organizational and technological tasks in agriculture on a high level of quality and deadlines. By the way, and climatic conditions abroad are 2.5 times more favorable than in the Volga region. The moisture content is the main factor of production efficiency, although there are some technologies that significantly regulate [8].

In recent years the republic has invested more than 150 billion rubles of funds raised in development of agricultural sector, this of course seriously increasing payables. Today it is 114 billion rubles, or $180 \%$ of the cash revenues. (Fig. 1).

High level of crediting limits new borrowings for updating funds and replenishment of circulating assets, especially during the period of preparation for spring field work and harvesting company. This factor has particularly strong impact on small forms of farming accounting for $50 \%$ of agricultural products of the republic.

Agricultural credit consumer cooperation today stands a successful alternative to the banking sector.

Agricultural credit consumer cooperative is a form of rural credit cooperation, established to meet the production needs of specific number of agricultural producers by accumulating temporarily available resources in the form of financial mutual fund for the purpose of lending and savings the funds of attracted shareholders and associated members on the basis of cooperative principles of activity.

In 2013, there were 32 agricultural credit consumer cooperatives in RT with 892 members, of which $73 \%$ came from peasant farming enterprise and private farms, they were granted loans for 63581 thousand rubles. The volume of attracted loans totaled 40764 thousand rubles. Over 1 billion rubles were issued as loans during 2006-2013. 


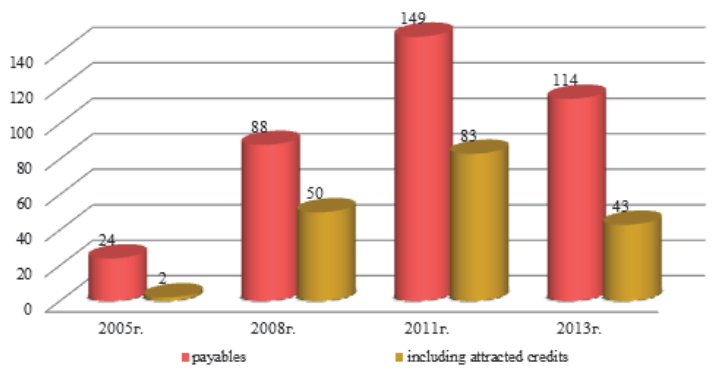

Figure 1. Payables of agricultural enterprises of RT, m rubles (- payables; - including attracted credits)

Active growth of lending occurred due to targeted state support. The main form of small enterprises' support is the allocation of concessional loans. In 2013 private households of citizens and peasant farms received 16,700 preferential loans worth 4.5 billion rubles. 116.7 thousand loans of 26.9 billion rubles were received totally for the years 2006-2013 by small forms of farming. 2.2 billion rubles was returned to population in grants for interest paid on loans (356.7 m in 2013).

\section{Result}

The greatest number of credits was received during the current year by Kukmorsky, Baltasinsky, Nurlatsky, Buinsky, Aktanyshsky, Muslyumovsky, Apastovsky, Mamadyshsky, Arsky municipal regions - 500 or more credits each.

At the same time there are still many problems in legal, technical, financial and economic support for credit cooperation.

These issues require settlement, and it is necessary to undertake a set of activities for establishing of rural credit cooperatives on the basis of organizational, financial, economic, informational, and other measures interconnected with each other by resource provision, executors, timeframes, namely [1, 2]:

1. Effective implementation of the State Program "Development of agriculture and regulation of markets for agricultural products, raw materials and food in the Republic of Tatarstan for 2013-2020" approved by the Cabinet of Ministers of the Republic of Tatarstan of 08.04.2013, № 235;

2. Development of formation mechanism for the agricultural credit cooperation system. Operation of agricultural credit consumer cooperatives will significantly simplify the procedure for obtaining loans by small forms of agricultural farming as well as by citizens being the partners of these cooperatives; and also provide them with other types of micro-financing

3. Interaction between government, local authorities and agricultural consumer credit cooperatives provision concerning various issues of joint activities, creation of conditions for development of infrastructure of credit cooperatives [10]. For these purposes, first of all, it is necessary to establish a mechanism for interaction between government, local authorities, cooperatives of low levels, taking into account the peculiarities of accounting and taxation system in ACC in areas such as:

- preparation and conclusion of agreements on cooperation between public authorities, local governments and agricultural consumer credit cooperatives ;

- Promotion of credit cooperatives creation - provision of municipal non-residential premises for ACC, establishing their different rates of rent, free regional media provision to inform public of ACC activities, etc.;

- assistance in formation and development of their material and technical base;

- assistance of district and rural settlements heads in selection of personnel, both in existing and in newly established agricultural credit consumer cooperatives;

- granting budgetary subsidies for start capital of ACC, creating material and technical base (Support Fund);

- subsidizing a part of the costs for payment of interest on loans in the banks attracted by agricultural consumer credit cooperatives for loans provision to the cooperative members;

- subsidizing a part of the costs of credit cooperative members for interest on loans payment obtained by them in cooperatives;

- creation of fund collateral obligations of ACC on loans attracted in banking institutions;

- provision of guarantees to the banking institutions of the Republic of Tatarstan on loans attracted by credit 
cooperatives of the second level, and municipalities for loans taken by ACC of the first level;

- subsidizing part of the costs associated with payment of commission under the guarantees to provide loans attracted by agricultural consumer credit cooperatives to provide credits and loans to members of cooperatives being the subjects of small businesses;

- inclusion of agricultural credit consumer cooperatives in regional programs to support small business development.

4. Promotion of investment attraction for the purpose of forming the financial mutual help fund in agricultural credit consumer cooperation.

The main goal of this event is spreading of positive experience of agricultural credit consumer cooperatives in the municipalities of the Republic of Tatarstan and popularization of rural credit cooperatives ideas of small farms in agriculture, small businesses in rural areas and rural population.

5. Creating the conditions for preparation and training of specialists in the field of credit cooperation.

The process of development of rural credit cooperation in the Republic of Tatarstan requires the development of adequate system of staff training and education to work in the provision of microfinance services, as a stable and efficient operation of existing and newly established agricultural credit consumer cooperatives largely due to high skill level of their managers and specialists $[7,9]$.

Functioning of appropriate educational infrastructure is necessary for training and development of managers and specialists of ACC. Existing and newly created agricultural credit consumer cooperatives are not able independently to finance its establishment and learning.

Implementation of the proposed set of measures will:

- $\quad$ increase the number of credit cooperatives and volume of rendered microfinance services;

- improve educational level of managers and specialists of rural credit cooperatives and business partners;

- stimulate the development of small farms in rural areas, significantly increase their role in socio-economic development of the Republic of Tatarstan;

- create more jobs in rural areas and increase the employment rate of population;

- $\quad$ attract additional investment in rural development and economy of the republic;

- implement saturation of the market of financial services with financial resources available to small businesses and rural population;

- $\quad$ promote cooperative ties between small and medium-size agribusinesses.

\section{References}

State Program "Development of agriculture and regulation of markets for agricultural products, raw materials and food in the Republic of Tatarstan for 2013-2020" approved by the Cabinet of Ministers of the Republic of Tatarstan of 08.04.2013, № 235.

Mavlieva L.M. The regional dimension of agricultural credit cooperatives [Text] / M.M. Nizamutdinov, L.M. Mavlieva / / Actual problems of economics and law. - Kazan: IEML Cognition publ., 2010. - № 1(13). - P.84 - 88.

Bagautdinova, N.G., Novenkova, A.Z., Sarkin, A.V. Quality management system formulation and implementation as a factor of enhancement of the university role in the local development // World Applied Sciences Journal, 27(13), 2013, 38-42.

Ajupov A.A. The Design and Use of Swap-Contracts in the Financial Markets // World Applied Sciences Journal, 27(13), 2013, pp. 1-4.

Safiullin L.N., Gafurov I.R., Safiullin N.Z., Bagautdinova N.G. Distribution and product selection under uncertainty / Recent Trends in Social and Behaviour Sciences - Proceedings of the 2nd International Congress on Interdisciplinary Behavior and Social Sciences 2013, ICIBSoS 2013 PP. $309-313$.

Ismagilova, G.N., Safiullin, N.Z., Bagautdinova, N.G., Safiullin, L.N. (2013) The Correlation of the Consumer Utility, Product Demand and Grade // Middle East Journal of Scientific Research 16 (10) PP. 1436 - 1440. doi: 10.5829/idosi.mejsr.2013.16.10.12062

Melnik, A.N. Problems and prospects of the formation of clusters in the power engineering / A.N. Melnik, A.R. Sadriev // World Applied Sciences Journal. - 2013. - v. 25.

Safiullin L.N., Bagautdinova N.G., Safiullin N.Z., Gafurov I.R. Influence of quality of the goods on satisfactions of consumers (2012) International GSTF Business Review (GBR).- Vol 2. - No 2, pp. 225-232.

Kirshin I.A., Gareev B.R. Theory of constraints in value based cost management // World Applied Sciences Journal (Economics, Management and Finance). - 2013. - №27. - P. 102-106.

Safiullin, M.R., Eflova M.U., Nagimova A.M. (2012). Social well-being and self-identification of the middle class in the Republic of Tatarstan. Sociologicheskie issledovaniya, 9, 28-32.

Glebova I.S., Rodnyansky D., Sadyrtdinov R., Khabibrakhmanova R. and Yasnitskaya Y. Evaluation of Corporate Social Responsibility of Russian Companies Based on Nonfinancial Reportingll Middle-East Journal of Scientific Research 13 (Socio-Economic Sciences and Humanities): 143-148, 2013. 